\title{
JUAN DE DIOS TORRALBO CABALLERO. UNA NUEVA POESÍA EN LA LITERATURA INGLESA: \\ DRYDEN Y POPE \\ Rosalía Villa Jiménez \\ Universidad de Córdoba
}

Received: 20 December 2013

Accepted: 17 January 2014

Juan de Dios Torralbo Caballero. Una nueva poesía en la Literatura Inglesa: Dryden y Pope. Sevilla: Ed. Alfar, 2013, 238 pp. ISBN: 978-84-7898-522-7.

Una nueva poesía en la literatura inglesa: Dryden y Pope brings generations of readers together not only through an accurate study of two of the major English writers of the English literary canon but also by addressing the underlying criticism of conventions along their literary works. Why John Dryden and why Alexander Pope? As the author claims, "Dryden es un escritor profesional del siglo XVII... de la Restauración porque vende sus obras de teatro y vende sus traducciones... siendo el primer escritor inglés que compone un corpus de obra crítica" (p. 131). Furthermore, he speaks of Pope as the father of satire and the heroic couplet, who criticises "a los poetastros o las malas prácticas literarias... gobernadas por la diosa Dullness" (p. 207).

The concepts of "literary career", "self-representation" and the "professionalization" of Dryden and Pope as writers in the "public sphere", though implicit, are the gist of the book. Key to these is the idea of moving from patronage, mirroring the medieval and renaissance system, to the appearance in monthly or weekly periodicals that guaranteed professionalization, independence and a breach of conventions.

The book mostly addresses the academic readership, lecturers and researchers, knowledgeable in the discipline related to the literary framework of the golden age England. More particularly, it supplements in part previous publications on the subject, "Andrew Sanders (1994), Ronald Carter y John McRae (1997), Michael Alexander (2000) o Robert C. Evans y Eric J. Sterling (2010)" (p. 14), to name but a few, as the book includes 
material with reference to translation theory and the impact of the writers' translations, mainly of classical masterpieces, on the publishing/reader market. In practice, milestones of the English literature, criticism and translation are undoubtedly worth reviving and rereading within the paradigm of the professionalization of the writer in the "new spacializations" of the bourgeois society and political life of the late puritan $17^{\text {th }}$ century and the early Augustan Age.

The author, Juan de Dios Torralbo Caballero, is a dedicated professor and researcher as well as translator, whose main field of expertise concerns the literary production of the $17^{\text {th }}$ and $18^{\text {th }}$ century England, with special interest in Dryden and Pope throughout their careers as poets, playwrights and translators.

As to the coverage of the book, Una nueva poesia en la literature inglesa: Dryden y Pope comprises five chapters and an extensive bibliography that accounts for Torralbo Caballero's hard work and meticulous attention to the development of the contents in each section.

The first chapter, Apuntes preliminares, "de carácter más general... pues este trabajo se ciñe a las figuras literarias de Dryden y Pope" (p. 24), as the author states in advance, displays a succinct account of the angle by which he approaches his object of study. Secondly, in terms of literary translation, Torralbo Caballero focuses on the notion of "authority" in a new emergent publishing market and Dryden's and Pope's postulation about translation theory, "metaphrase, paraphrase and imitation" (p. 213). Lastly, the author highlights the importance of literary intertexuality so as to fathom the what, how and why of the literary works at issue.

In regard to the second chapter, El panorama literario, the author provides a brief but exemplary literary framework covering from Dryden to Pope in order to give a theoretical background to the ensuing sections. Chapters three and four, La carrera literaria de John Dryden and La singularidad de Alexander Pope respectively, encompass their literary careers, thereby establishing a well-defined linkage between the sociopolitical and historical milieu of the $17^{\text {th }}$ and $18^{\text {th }}$ centuries and the production of their works. Finally, chapter five, A modo de conclusiones generales, provides a conclusion to underline the transcendence of Dryden and Pope placed within a context, likewise, "vinculando a ambos autores en la medida de lo posible" (p. 25).

Of great value is the preference for a clear methodological approach along with a most welcomed clarity of style, a detailed presentation of the objectives pursued, a clear-cut division of the chapters in the book, an 
explicit theoretical framework and an ample illustrative selection of poems of the poets concerned, which altogether most befittingly tinge the whole book with the Horatian prodesse et delectare.

In terms of methodology, an intertextuality construct, and consistent division of the book, the author places both writers and their respective literary creations within a conceptual framework, which is mandatory in order to better understand the singularity of each literary figure. In like manner, the selection of poems is thought of as a pathway for the reader to closely interact with the milieu of the $17^{\text {th }}$ and $18^{\text {th }}$ century England, "Estudiar los textos únicamente desde el presente, coincidimos con Fish, no es un procedimiento de trabajo ... Mejores resultados pensamos que arroja un abordaje empirista y contextual, partiendo de la inmanencia textual y a la vez considerando los factores generadores de la eclosión del texto sin desdeñar, asimismo, algunos rasgos autobiográficos relevantes de su autor" (p. 12).

Worth praising as well is the fluidity that characterises chapter two, El panorama literario, which easily moves on from a political and social overview of the age, the literary trends of the time, and finally to the new advent of verse - both male and female - within the metaphysical, cavalier, love, libertine, devotional, loco-descriptive and the satire subgenres of the $17^{\text {th }}$ and $18^{\text {th }}$ centuries, which in fact receive more attention on the part of the author, who ventures to give his own reading of the poems selected.

Strange as it may be at a first glance, the chapter draws to its end with a succinct and separate but illustrative account of a number of literary translations as the author prefers to "recogerla [literary translation] en un epígrafe diferente, aunque sea a través de una selección de muestras, ya que es el oficio mismo de la traducción el que llama la atención del estudioso" (p. 79). Hence, in this context, Torralbo Caballero finds it more comfortable to pave the way for dealing with Dryden's and Pope's role both as writers and translators in the following chapters, respectively. In turn, at this extent, a more consistent argument about translation is missing.

Considering the chapter as a whole, it provides an actual condensed historical and political as well as social and literary theoretical background ranging from the early $17^{\text {th }}$ century to the first decades of the following hundred years. Notwithstanding, even if the author's intent was to present a concise social, political and historical overview of this period, it would be advisable to give a more elaborated elucidation of the occurrences that influenced on Dryden and Pope as a way of compensation among the sections and would as well paying more attention to the writers and literary 
trends mentioned that in point of fact left a real imprint on Dryden's and Pope's literary careers.

Undoubtedly, the major strength of Torralbo Caballero's book is the rigorous research on Dryden and Pope. As far as chapter three is concerned, the author attempts at arousing the reader's interest with a meaningful introductory battery of questions regarding the writer's place in the "public sphere", anticipating thus Dryden's journey from lyricism to the theatre and translation, as he puts it, “¿Por qué no se imprimen [Dryden’s works] en paperback ejemplares de MacFlecknoe y por qué no abunda la obra de Dryden en los anaqueles de las librerías?” (p. 88) or “¿Por qué se dedica Dryden en estas dos etapas de su vida a escribir obras para la escena? ¿Por qué invierte sus últimos esfuerzos creativos en la traducción literaria?” (p. 88).

Especially, he manages to cover all the objectives discussed in the first chapter concerning Dryden by interweaving fact and fiction in consonance with the methodological approach proposed, "En 'Behold another silvestre, to bless / The Sacred Standard, and secure Success' (84-85) está aludiendo al Papa Constantino y, a su vez, a la Santa Sede ... Meses después Jaime II está en el exilio y la Casa Real la ocupan Guillermo y María” (p. 106). Likewise, Torralbo Caballero takes up the issue of professionalisation and self-representation, mentioned at the very beginning, concerning Dryden as a poet and translator always with a back-up statement that perfectly reminds the reader that his professional career must need to be explained always bearing and the $17^{\text {th }}$ century atmosphere in mind, "Cuando, siendo fiel a sus ideas católicas, pierde las prebendas del patrocinio que les dispensan desde el poder, explora y consigue otra vía, que es la profesional, pues cultiva la traducción de textos antiguos (sin copyright) para su posterior venta... el segundo modelo le genera pingües beneficios" (pp. 123-24).

Of equal substance is La singularidad de Alexander Pope, perceived as a continuation of chapter three in reference to the historical, socio-political and literary timeline. As well, Pope masters the heritage of the verse and satire of the $17^{\text {th }}$ century and embraces the scope of Neoclassicism, which gives a more universal brushstroke to his works with a nostalgia for the primitive and uncorrupted, "Pope despierta su primera vocación literaria con la poesía pastoril" (p. 134).

In chapter four, the author clearly remains faithful to the pillars of the book, without forgetting to merge the singularities of both figures. At a more general level, Torralbo Caballero provides an overview of the Augustan Age to finally come down to the genesis and development of 
Pope's accomplishments. Thereby, he succeeds in fostering the reader to fully and easily understand the rationale that prompted Pope to dedicate himself to criticism along his literary professional career through his pastorals, his comic-heroic satires, his role as an acknowledged translator and through his interest in cultivating the satiric subgenre at a first, second and third stage, respectively.

On top of that, if any, a weakness in terms of the contents in this chapter is the exhaustive study of Pope as a translator of the Classics that far exceeds that of his predecessor. Similarly, a brief but detailed summary of Pope's contribution to translation theory is missing so as to complement Dryden's.

By and large, Una nueva poesía en la literature inglesa: Dryden and Pope presents some drawbacks to be sure. Then it is suggested the author could nimbly amend them in forthcoming publications. As to the structure, the book is well polished and breathes unity as well as clearly focuses on covering the objectives pursued, disclosed at the very beginning. In addition, the author supplies the reader with a lucid explanation of every chapter in a dynamic way by furnishing the text with a good many examples. The book provides a valuable window into the literary body of the $17^{\text {th }}$ and $18^{\text {th }}$ centuries, adding great emphasis on Dryden and Pope, and touching upon their careers as translators, sometimes overlooked in literature. 